\title{
NALORPHINE IN THE PREVENTION OF OPIATE-INDUCED NEONATAL NARCOSIS*
}

Frederick Prescott, Ph.D., M.R.C.P. (Lond.) *

DEMERol and, to a lesser extent, morphine, with or without scopolamine, are administered as obstetric analgesics. Relief to the mother is often bought at the cost of respiratory and circulatory c epression in the newborn. The extent to which this occurs is variable as it depenc s on the dose of drug and the tme that it is given before delivery. It is more likely to occur if opiates are given to the mother within two or three hours of delivery. The incidence of neonatal asphyxia due to the administration of demerol or morphine to the mother is said to be from 7 to 21 per cent $(4,8,9,12,16)$. It is not realized that in the adult demerol is almost as potent a respiratory depressant as morphine. If a normal subject breathes a muxture of oxygen with 5 per cent carbon dıoxide, respiration is stimulated threeto five-fold After the administration of demerol this response to carbon dioxide stimulation is reduced to 60 per cent. Either demerol is less depressant than morphine in the newborn or the placenta is less permeable to it, because it causes less depression than morphine in the newborn.

Until recently the treatment of babies born with respiratory and circulatory depression due to over-dosage of the mother with potent analgesics was by mechanical stimulation, artficial respiration, and the administration af analeptics. A specific pharmacological antagonıst of morphine is, however, now available in the form of nalorphine or N-allylnormor phine ("Lethidrone" or "Nallıne"). This will antagonize most of the pharmacological actions of morphine, such as respiratory and circulatory depression, depression of the reflexes, inhibition of gastrointestinal movement, increased pressure in the bile duct, and antiduretic action. Not only is nalorphine a morphine antagonust but it is a pharmacological antagonist to all analgesics with a morphine-like action, such as demerol (pethidine), heroin, levorphan (dromoran), dilaudid, metopon, methadone, and nisentil. It has been used in the resuscitation of patients receiving over-doses of these. In man, approximately 4 to $5 \mathrm{mg}$. of nalorphme antagonizes $50 \mathrm{mg}$ demerol, or $5 \mathrm{mg}$. morphine (1).

In subjects heavly narcotized with opiates, nalorphine dramatically stimulates respiration, restores superficial and deep reflexes, including the cough reflex, and raises lowered blood pressure. The effect is often exerted within a minute or two unless the opiate dosage has been very high

In heavily morphinized patients nalorphine alters the electroencephalographic pattern trom that of deep sleep to that of the waking state (6) and in morphine addicts it evokes the typical abstinence syndrome (15). It probably acts by competung with morphine or other opiates at certain cell receptors and displacing them, just as the sulphonamides compete with PABA, and prevent its being utilized by bacteria. There is an optimum antagonistic dose of nalorphine for a

'Presented at the Annual Meeting of the Canadian Anaesthetists' Society, Toronto, June 20, 1955.

*Wellcome Research Instıtution, London, England. 
given dose of opiate. This means that the dose is critical. If insufficient is given, the opiate is not displaced from the cell receptors; if too much is given, the opiate is displaced and the excess of nalorphine produces its own pharmacological effect. Nalorphine alone has a mild morphine-like action and in $5 \mathrm{mg}$. to $10 \mathrm{mg}$. doses in man can depress respiration by 30 to 50 per cent, and produce tiredness, drowsiness, nausea, vomiting, and pallor. In large doses it has an analgesic effect on man (11).

There is some evidence that when nalorphine is given in combination with morphine and in excess of the dose necessary to just antagonize the latter, the effects of the two are additive (10). Lasagna and Beecher (11) state that in man a combination of $5 \mathrm{mg}$ nalorphine and $15 \mathrm{mg}$. morphine produces respiratory, depressant, and subjective side effects similar to those obtained with $15 \mathrm{mg}$. of morphne. Nalorphine is specific only in its antagonısm to morphine-like compounds. It is ineffective in relieving respiratory and crrculatory depression due to other drugs such as inhalation anesthetics and barbiturates, when administered intravenously or by any other route.

\section{Use in Neonatal Narcosis}

Nalorphine was first used by Eckenhoff, Hoffman, and Dripps (6) as an antagonist to neonatal narcosis produced by sedation of the mother with opiates They gave $10 \mathrm{mg}$ nalorphine intravenously to mothers ten munutes before delivery. These patients had been given $200 \mathrm{mg}$. demerol, as well as seconal and scopolamme within the previous five hours. A control group was given salıne in place of nalorphine. Babies born under the influence of nalorphine gasped and cried within half the tume taken by those whose mothers had not received the drug. Twelve depressed infants received 01 to $02 \mathrm{mg}$. nalorphine directly into the umbilical vein within 5 to 10 minutes of delivery The result in eleven was prompt appearance of respiration, improvement in colour and muscular tone, and sustained crying In a later study Eckenhoff and his associates (7) described a similar investigation in 1,100 cases of labour There was a significant reduction in the need for resuscitation, and in the time required for the infants to gasp and breathe when born of mothers who had heavy demerol sedation, and who had also $10 \mathrm{mg}$. of nalorphine intravenously within 15 minutes of expected delivery.

In 1953 Dr. Paterson and I carried out an investigation on the reduction of neonatal narcosis by nalorphine The respiration of 203 unselected and consecutive infants whose mothers had been given demerol or "Pantopon" during labour was carefully observed. The total dose of demerol varied from $100 \mathrm{mg}$ to $300 \mathrm{mg}$. The doses and tmes of administration of the drugs were recorded and the foetal heart rate counted every 15 mmutes for two hours after giving the drugs. After delivery the cord was not cut untl the infant had gasped and cried, and the times when it did this were noted. If the infant did not gasp within 10 seconds of delivery $0.5 \mathrm{mg}$. nalorphine was given into the umbilical vein. If the infant did not cry within 2 minutes and the cord was still pulsating the dose was repeated. The controls consisted of 205 unselected consecutive obstetric cases, 7 of which were twin births, making the total number of infants 212. Demerol or sometimes "Pantopon" was given to the mother during labour, but the infants were not given nalorphine. The obstetric histories of the nalorphine-tr eated series and the controls 
were similar. Asphyxia was diagnosed in the controls if breathing did not start within 2 minutes, if active resuscitation was necessary, and if the baby was limp and slow to breathe.

In the control series, neonatal asphyxia was present in 34 of 212 infants ( 16 per cent) and 31 of these required resuscitation. Of the 203 infants in the nalorplinetreated group, 28 ( 14 per cent) were given nalorphine because of asphyxia, ard in 12 of these active resuscitation was requred. It was not thought jusifiable to withhold it to see if the infants would eventually breathe spontaneously. It is seen that the incidence of neonatal asphyxia was approximately the same in both nalorphine and control serries.

Of the 28 babies that received nalorphine, 8 gasped imrnediately after the injection and 14 within half a minute. Hence within half a minute, 80 per cent of all treated infants had gasped. Sixteen or 57 per cent cried within 4 minutes after the injection. Of the 21 controls for whom the information was recorded, 8 or 31 per cent cried within 4 munutes. There is a difference between the two percentages, 57 and 31 per cent, but it is not highly significant $(P=0.19$ ).

Active resuscitation was needed in 12 of the 28 babies (or 43 per cent) who recelved nalorphine. In the controls resuscitation was necessary in 31 out of 34 , or 91 per cent. The difference between these two percentages is highly significant $(\mathrm{P}=0.001)$ in favour of the babies treated with nalorphine.

\section{Discussion}

The dosage of nalorphine for adults is probably in the region of $10 \mathrm{mg}$. The dose for the newborn in this series was $05 \mathrm{mg}$., which was arrived at on the basis that the weight of a newborn infant is about one-twentieth that of an adult. Eckenhoff and his co-workers used 0.1 to $0.2 \mathrm{mg}$. and Chalmers and Thornberry (3) in a small series employed $0.25 \mathrm{mg}$. The latter gave this dose to eight infants who had shown no signs of respiration within a short time of delivery and whose mothers had been given morphine or pethidine durng labour The only case in which the trèatment was ineffective was attributed to respiratory depression by inhalation anaesthetics. It is possible that a lower dose than the one used in this trial, that is $0.5 \mathrm{mg}$., would have been effective Another controlled trial would be necessary to determine this. While no ill effects were attributed to nalorphine in any of these infants, we do know that an overdose in normal adults leads to depression of respiration, sweating, pallor, and depression of the cough reflex. Cappe, Himel and Grossman (2) gave a mixture of $15 \mathrm{mg}$. morphine, $0.4 \mathrm{mg}$. hyoscine hydrobromide, and $1.5 \mathrm{mg}$. nalorphine to 26 patients in active labour. All the infants except one breathed and cried spontaneously at birth; only one showed respiratory depression. According to these workers the mothers experienced relief from pain. Lasagna and Beecher (11) have shown that while ralorphine has no significant analgesic action in man in doses of $5 \mathrm{mg}$. or less, in larger doses it is analgesic.

It would seem that the most practical way of giving nalorphine is to administer it to the infant rather than the mother, and only to give it when required. The infant's condition at birth must be carefully assessed, and the cause of asphyxia diagnosed, if possible before any more drugs are administered. Not all cases of neonatal respiratory and circulatory depression are due to excessive dosage of 
the mother with opiates. Possibly half are, although Roberts (14) attributes only 14 per cent of cases to over-sedation of the mother. The use of nalor shine should permit the increased use of opiates nearer to the time of delivery thian has been considered safe in the past. Hitherto caution has been exercised in giving such drugs within two or three hours of delivery and in repeating the dose even if the mother's condition warrants it. It is also possible that nalorphine will permit the increased use of morphine in obstetrics.

\section{SUMMARY}

The use of nalorphine ( $\mathrm{N}$-allylnormorphine) as an antagonist to morphine and the opiates is diseussed. A dose of $10 \mathrm{mg}$. in the adult reverses most of the sharmacological actions of clmical doses of the opiates; the dose is critical. Nalorphine can be used to prevent respiratory and curculatory depression in the newborn due to over-dosage of the mother with drugs such as morphine and demerol. If the baby is born with signs of asphyxia, or it does not breathe readily, $0.5 \mathrm{mg}$. nalorphine is injected into the umbilical veın. Of the babies treated, $80 \mathrm{per}$ cent gasped within half a minute. It is possible that the use of nalorphine will enable opiate drugs to be used nearer the tume of delivery

\section{RÉSUMÉ}

L'auteur traite de l'emplo1e de la Nalorphine ( V-allyl normorphine) comme antagoniste de la morphine et des opiacés. Une dose de $10 \mathrm{mg}$. chez l'adulte fart disparaitre la plupart des effets pharmacologiques des doses cliniques d'opiacés; c'est une dose critique. La Nalorphine peut être employée pour prévenir la dépression respiratoire et circulatoire chez le nouveau-né quand la mère a reçu des quantités nocives de morphine ou de demerol. Si le bébé à sa nasssance présente des sıgnes d'asphexie ou ne respure pas immédiatement, on injecte $0.5 \mathrm{mg}$. de Nalorphine dans le veine ombilicale, 80 pour cent des bébés traités de cette façon commencèrent à respirer en moins d'une demie minute. Il est possible qu'avec l'emploie de la Nalorphine on pourra utiliser des opiacés avant la délivrance.

\section{REFERENCES}

I Bodman, R I Proc Roy Soc Med 46. 923 (1953)

2 Cappe, B. E, Himet, S Z \& Grossman, F Am. J Obst \& Gynec 661231 (1953)

3 Chalmers, J A \& Thomnderhy, C J J Obst \& Gynaec Brit. Emp 61244 (1954)

4 Cripps, J. A R, Hall, B \& Haultain, W F T Brit Med J 2498 (1944).

5. Eckenhoff, J. E., Elder, J. D, Jr. \& King, B D Am J. M Sc 223191 (1952)

6. Eckenhoff, J E, Hoffman, G. L \& Dripps, R. D Anesthesiology 13242 (1952)

7. Eckenhoff, J E, Hoffman, G L, Jr \& Funderburg, L W. Am J Obst \& Gynec 65 1269 (1953)

8. Gallen, B \& Prescott, F Lancet 1. 176 (1944).

9 Grleert, G. \& Dixon, A B Am J. Obst \& Gynec 45320 (1943)

10 Gruber, C M J Pharmacol \& Exper Therap 111409 (1954).

11. Lasagna, L \& BeEcher, H K J Pharmacol \& Exper Therap. 112.356 (1954).

12. O’Reuly, P. J. Lancet 2. 1012 (1948).

13. Paterion, S \& Prescott, F Lancet 1. 490 (1954)

14. Roberts, H Brit Med J 2590 (1948)

15. Wikter, A., Fraser, H F \& Isbell, H J Pharmacol \& Exper Therap 1098 (1953).

16. Winters, H S, Garcia, C. R \& Lubin, S. Am J. Obs.. \& Gynec. 6 I 629 (1951) 